\title{
Community Participation on Tourism Development in Parangtritis Tourism Area, Bantul Regency
}

\author{
Meitolo Hulu ${ }^{1}$, M.Baiquni ${ }^{2}$, Chafid Fandeli ${ }^{3}$, Niken Wirasanti ${ }^{2}$ \\ ${ }^{1}$ Doctoral Student in Tourism Studies Gadjah Mada University, Indonesia \\ ${ }^{2}$ Gadjah Mada University, Indonesia \\ ${ }^{3}$ Institute Technology of Yogyakarta, Indonesia \\ Corresponding author: meitolohulu@yahoo.com
}

\begin{abstract}
ARTICLE INFO
Received

07 February 2019

Accepted

05 September 2019

Available online

30 September 2019

Parangtritis tourist area is a famous tourist destination in the south of Yogyakarta. The tourist area which consists of a variety of tourist objects such as beaches, sanddune, culinary, religious and cultural tourism has a positive impact on the growth of tourist visits in Parangtritis tourist area. This study aims to examine the participation of local people in their contribution to the development of sustainable tourism areas. The method used in this study is descriptive qualitative by conducting primary and secondary data collection. Primary data was collected through interviews with local communities which involved in to the service industry, cultural arts groups and local government of Bantul Regency. The results of the study are (1) the local community has contributed to the development of the Parangtritis tourist area through local cultural activities, tourist attractions and providing of facilities regarding the needs of visitors. (2) the local government of Bantul Regency has several programs related to the empowerment in each of government institution that are addres service industry, tourism local groups and build facilities and infrastructure. But the contribution of local communities has not become a tourist attraction and sustainable. Empowerment programs from local governments have not been specific to training related to services and business activities that are suitable for tourism activities in Parangtritis tourist area.
\end{abstract}

Keywords: Community participation, tourist area, sustainable tourism.

\section{INTRODUCTION}

\section{Background}

Parangtritis tourist area is a famous tourist destination in the south of Yogyakarta. The tourist area which consists of various tourist objects such as beaches, sand dune, culinary, religious and cultural tourism has a positive impact on tourist visits in Parangtritis tourist area. The activities of the local community as farmers and fishermen have gradually 
shifted to tourism activities. The development of tourism has a positive impact on business opportunities and at the same time increases people's incomes (Woosnam et al., 2009). The involvement of community in tourist service industry face several challenges. As tourism known as serving tourists, requires adjustment to the local community. Because of the involvement in tourism service industry activities is not about just selling and getting profits, but the level of comfort and satisfaction of tourists is a benchmark for the continuity of tourism activities.

Tourism activities can reduce the quality of natural resources, environmental degradation, and damage to ecosystems in the destination if not developed in sustainable way (Neto, 2003; Mihalič, 2000; Cohen, 1978; Miller and Auyong, 1991). For this reason, development must refer to a planned and future perspective in accordance with its environmental capacity (Pigram and Wahab, 2005). Tourism activities can be at risk for land use that is not in accordance with its designation such as hotel construction, facilities, clean water, excessive use of marine resources, incomplete handling of waste, increased pollution, activities that exceed of carrying capacity of destinations can threaten environmental sustainability
(Elliott, 1997; Murray, 2007; Neto, 2003; Zahedi, 2008).

Sustainable development must be integrated with the fulfillment of environmental sustainability criteria, community involvement, cultural preservation, and local economic benefits (Sano et al., 2010). For the community, the business opportunity is a right for all local residents, but in its development it creates problems. Many tourism service industry do not have operational permits and even are doing in conservation areas. This situation continues to occur and often gets warnings from the local government. Local communities have a significant role in developing tourism, because of he community is one of the stakeholders in tourist destination. The benefits of tourism development will also be accepted by local communities if managed properly and sustainably.

The attraction of Parangtritis tourist area consists of natural tourism, cultural tourism and artificial tourism. The combination of tourism potential makes Parangtritis tourist area is a strategic tourism area in Bantul Regency. Determination of the Parangtritis area as a regional strategic tourism area is supported by the development of facilities and infrastructure including management of tourist areas that can bring benefits 
(Regional Regulation no.18 of 2015 concerning Bantul Regency RIPKD). The development of tourist destinations in Yogyakarta especially beach tourism adds to the enthusiasm of visitors to choose the coastal area as a destination.

The south coast of Yogyakarta covers three regencies which each make the coastal area as a priority destination. Kulon Progo Regency has a beach, as well as Gunungkidul Regency which has many coastal areas. Based on observations on this research the coastal area is still the main priority visited besides other tourist areas. Data on tourist visits to the tourist area of Parangtritis in the last five years shows a significant increase in number every year. This data shows that the tourist area of Parangtritis is still to be the main tourist destination that in Bantul Regency. The following chart of number of tourist visits in the last five years.

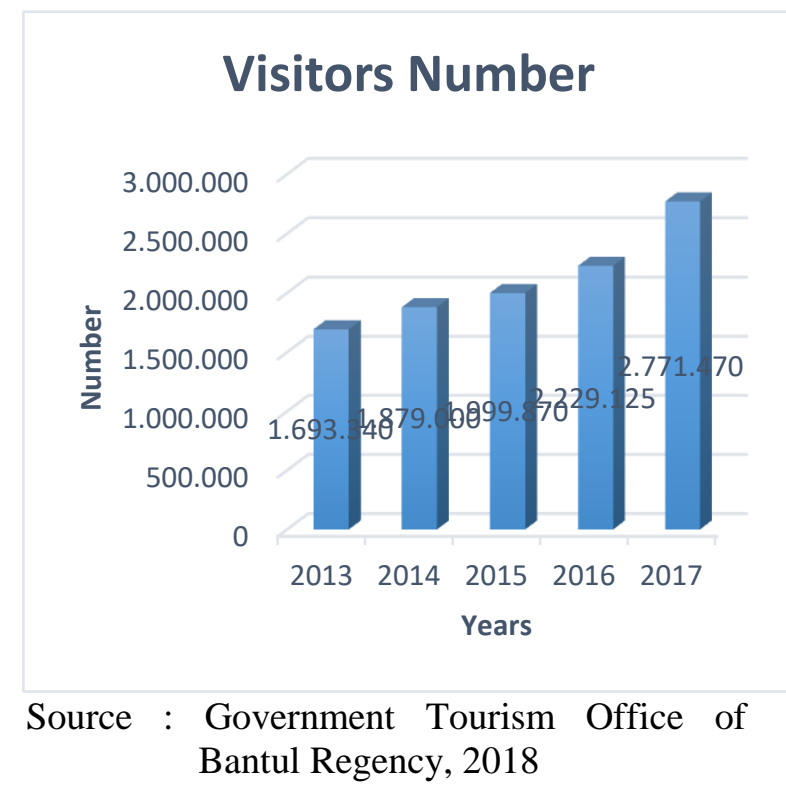

http://ojs.unud.ac.id/index.php/eot
The increase of number of tourist visits based on the chart above shows a positive signal to the community and local government. The increase in tourist visits impact on tourism activities and at the same time have an impact to the local community as a tourist service industry. Likewise, the local government of Bantul Regency received benefits from the increase in tourist visits which resulted in an increase in local government revenue.

Local community are involved in managing tourism service industry in Parangtritis tourist area. Parangtritis tourist area which includes Parangtritis beach, Parangkusumo beach, sand dune area, depok beach, Depok lagoon, and pilgrimage place are divided into four working groups. The working groups are;1) Parangtritis working group, 2) Parangkusumo working group, 3) Depok working group, and Depok lagoon working group. Each working group has almost the same tourism potential, but its different in its management. Many similar tourism service industry growing up, and further reduce the visitor's space. For example shops building, toilets and swimming pools that can reduce the level the convenience of visitors.

\section{Objectives of Research}

This study aims to examine the form of local community participation that e-ISSN: 2407-392X. p-ISSN: 2541-0857 
contributes to the development of a sustainable Parangtritis tourism area.

\section{LITERATURE REVIEW}

\section{Sustainable Tourism}

Tourism potential in the form of natural beauty, local traditions and uniqueness must be maintained and preserved as assets that can be utilized. The utilization of tourist assets must be carried out by considering their sustainability, so it can be beneficial to local communities (Yang et al., 2016). Tourism activities in several destinations have an impact on environmental damage, and a lack of attention to available natural resources (Mihalič, 2000). Decreasing environmental quality influences to the image of the destination because of the tendency of pollution, cleanliness and growth of buildings that are not in accordance with their designation (Murray, 2007, Zahedi, 2008).

One of the benefit of tourism development is the opening of employment opportunities for local residents (Woosnam et al., 2009). Tourism activities encourage the creation of new tourism service industry that provide tourist needs and at the same time to be a kind of service for tourists. The coastal tourism area has a lot of potential that can be developed, so it needs to maintain the quality of its environment from negative impacts (Hall, 2001). Negative impacts can be minimized through the use of natural resources in sustainable way (Neto, 2003).

\section{Community Participation}

Tourism activities that take place in tourist areas have a positive or negative impact on local communities. According to (Singh et al., 2003) that local community participation involved in making decision for the planning process of tourism activities which includes social, cultural and environmental issues. The participation of local people in managing coastal areas is constrained by many factors (Siry, 2011). Tourism activities are still doing in short term and do not meet the sustainability aspects related to the development of tourist facilities (Davenport and Davenport, 2006). The involvement of local communities in tourism service industry and as well as workers is expected to increase awareness of the importance of developing sustainable tourism areas.

\section{RESEARCH METHODS}

The method used in this study is descriptive qualitative by conducting primary and secondary data collection. Primary data was collected through interviews with local communities, 
tourism service industry, cultural and arts groups in Parangtritis tourist area, and the local government of Bantul Regency. The Parangtritis tourist area covers the area of Parangtritis Village which consists of various types of tourism are natural tourism, cultural tourism, and artificial tourism. Direct observation in the field is done to see more clearly the condition of the Parangtritis tourist area to strengthen the results of interviews. Secondary data collection is carried out through the study of documents, audio visuals, images related to the development of sustainable tourism and the development of the Parangtritis tourist area. The selection of informants was done by purposive sampling, which was to determine the informants who mastered the information and at the same time were involved in developing the Parangtritis tourist area.

Informants from the community are administrators of tourism local groups, tourism service industry and local community leaders. Then the informants from the local government are dovernment institutions related to tourism activities and also Parangtritis Village officials who have programs and policies in developing the Parangtritis tourist area. Data is analyzed by linking themes or descriptions according to facts in the field, then objectives of this study.

\section{RESULTS AND DISCUSSION}

\section{Tourism Potential}

The development of the tourist area of Parangtritis is supported by a number of attractions such as natural attraction, cultural attraction, and artificial attraction. Parangtritis tourist area is known as "Tri Roh", which is the area covering Cepuri, the Tomb of Shekh Maulana Mahribi and the Tomb of Shekh Belabelu (Center for Planning and Tourism development UGM, 2000). The type of attraction in the tourist area of Parangtritis is shown in table 1 below.

Tabel 1. Destinasi Wisata di Kawasan Parangtritis

\begin{tabular}{|c|c|c|}
\hline No & Tourist Object & Category \\
\hline 1 & Pantai Parangtritis Beach & Nature \\
\hline 2 & Parangkusumo Beach & Nature \\
\hline 3 & Pelangi Beach Beach & Nature \\
\hline 4 & Cemara Sewu Beach & Nature \\
\hline 5 & Depok Beach & Nature \\
\hline 6 & Lagoon of Depok & Nature \\
\hline 7 & Sand Dune & Nature \\
\hline 8 & Hot Water "Parang Wedang" & Nature \\
\hline 9 & Cepuri & Culture \\
\hline 10 & Tomb of Shekh Maulana Mahribi & Religion \\
\hline 11 & $\begin{array}{c}\text { Tomb of Shekh Belabelu dan } \\
\text { Syekh Damiaking }\end{array}$ & Religion \\
\hline 12 & Gardu Action & Artificial \\
\hline 13 & $\begin{array}{c}\text { Education Village "Watu } \\
\text { Lumbung" }\end{array}$ & Artificial \\
\hline 14 & Sand Dune Museum & Artificial \\
\hline
\end{tabular}

Source: Parangtritis Village, 2018

e-ISSN: 2407-392X. p-ISSN: 2541-0857 
The combination of the beauty of nature, and the strength of culture is the uniqueness of Parangtritis as a tourist attraction. The development of the Parangtritis area as stipulated in regional regulation number 4/2015 concerning the spatial plan and territory of Bantul Regency is designated as an economic strategic area, environmental area, agricultural area, coastal border area, defense and security area, and tourism area.

\section{Tourist Services Industry}

The source of income of local community in Parangtritis Village comes from various sources. Getting income from agricultural products and also from the involvement to the tourism services industry that are growing. Many people have set up lodging as well as houses and other tourism service industry who get benefit from increasing the tourist visits.

Tabel 2. Tourist Service Industry Parangtritis Tourist Area

\begin{tabular}{|l|l|l|l|}
\hline No & Jenis Usaha & No & Jenis Usaha \\
\hline 1 & Shops & 9 & umbrella/Mat \\
\hline 2 & All Terrein Vehicle & 10 & Benda (Horse) \\
\hline 3 & Car Jeep & 11 & Souvenir Shopd \\
\hline 4 & Asongan & 12 & Toilet \\
\hline 5 & Swimmimg Pool & 13 & Park Area \\
\hline 6 & Sand Boarding & 14 & Sun Glasses \\
\hline 7 & Garden of Folwers & 15 & Accomodation \\
\hline 8 & Photo & 16 & Angkringan \\
\hline
\end{tabular}

Sumber: Field observation, 2018
The growth of tourist services industry is in line with the increase with tourist visits in Parangtritis tourist area. Initially the existing service industry was limited to meeting the needs of accommodation, food and drink for visitors. However, now tourism services indusrty are developing towards meeting the needs of tourist activities, such as ATVs, Jeeps, freshwater swimming pools, etc. (see Table 1). There are many tourism service industry that operate without the permission of the local government regarding the operational standards of activities. The following is an interview to the one of the shops owners, Mrs Ira said.

"We've lived here (beach area) from the 90s, at first I opened a shop for the needs of fishermen and visitors who at that time were not as busy as now. So I don't know about the business permits. In the past, there were still a few of us, but now we can more shops and other service industry. Usually when a holiday come or in the end of the week a lot of visitors come here, they buy food and drink. Recently, here are also increasing types of businesses. Like ATVs, Car Jeep, swimming pools are all just emerging ".

The local government of Bantul Regency through the Tourism Office in collaboration with the relevant government office has programs related to training and 
business development, but not for every one in the group can touch. The group equalization program or the distribution of training quotas, programs only touch at the level of management and do not touch individually ${ }^{1}$. The development of the Parangtritis tourist area has a positive impact on the economy of the local community. From the economic aspect it has had an impact on employment opportunities and small-scale enterprise fields, but it still does not accommodate all the people in Parangtritis Village.

The type of business that has sprung has caused conflicts among business actors regarding their zone of business and management. The decreasing condition of Parangtritis from the performance aspect push a group of people called Peduli Parangtritis (Parangtritis Care) to organize a growing tourism service industry. The Parangtritis Care was established with the aim of preventing the entry of hawkers into the coastal area which could disrupt visitors' movement. The Parangtritis Care, which consists of local people and tourism service industry is still not maximally managing the tourism services, because each member has a business an do not have operational permits as standarized by local government. This condition make the

\footnotetext{
${ }^{1}$ Interview with Tourism Government Staff and Industrial Service Staff of Bantul Regency 2018 http://ojs.unud.ac.id/index.php/eot
}

Parangtritis Care only focus on hawkers who come from the outside of Parangtritis area.

Tourist service industry activities in Parangtritis tourist area affected to the decline in the quality of Parangtritis tourism it self. For example the business of freshwater swimming pools, Jeeps, ATVs on the beach clearly reduces visitors' comfort. Flower garden businesses and tourist attractions in the sand dune zone are contrary to efforts of sand dune restoration. Tourism business activities that are not in accordance with their uniqueness have a negative impact on visitor comfort and at the same time reduce the quality of destinations (Hulu et al., 2018). Because the tourism sector is very susceptible to physical and image changes which ultimately has an impact on tourist visits (Baiquni, Susilowardani 2002). The number of tourist activities such as in sand dune, coastal areas and land use that are not in accordance with its designation has a negative impact on the environment in Parangtritis tourist area ${ }^{2}$.

\section{Art and Culture Group}

The livelihood of the people of Parangtritis Village has shifted after Parangtritis became growing as a tourist

\footnotetext{
${ }^{2}$ Interview with pollution and conservation section of the Environmental Services Bantul Regency, 2018
} 
area. The community that used to be a farmer and fisherman was attached as a source of hereditary livelihood. The shift in people's livelihoods from farmers and fishermen to tourism actors requires full assistance from the local government. An interview with Mr. Parianto, Yogyakarta cultural observer said that:

"Changes in the times need to emphasize cultural values for future generations, because culture can unite opinions to build a nation, Parangtritis will be more advanced if it is built on local cultural values".

Planting local cultural values which are Parangtritis's identity must synergize with tourism activities. The Parangtritis tourist area known as ritual tourism, religious tourism and beach tourism must be a mutually reinforcing series as an attraction for visitors. The development of Parangtritis tourism is still dominated by tourist attractions that have not represented the existing tourism potential. Art and cultural activities such as Ketoprak, puppet shows and traditional music have not been included in the routine agenda that can attract visitors. Based on the interviews with the management of arts and cultural groups said:

"The existence of arts and culture groups in Parangtritis is still not active in staging http://ojs.unud.ac.id/index.php/eot his work, because it is not supported by funding and mobilizing initiators."

Organizing art shows requires support from both material and nonmaterial aspects. This is experienced by managers of arts and culture groups in the tourist area of Parangtritis. The driving initiator in question is a person who becomes a leader and has the capacity to understand local arts and culture. Regarding material support, the special regional government of Yogyakarta through privileges has funds allocated to support arts activities and strengthening local culture, but still has not been fully utilized by arts and cultural groups in Parangtritis tourist area ${ }^{3}$.

\section{CONCLUSION}

The arrangement of the Parangtritis tourist area is very necessary to restore the beauty of the beach and the uniqueness of the barchan sand dune which is a tourist asset of Parangtritis. Tourist services industry activities require management in accordance with service standards that can provide satisfaction to visitors. Parangtritis tourism potential must be able to synergize with the environment and local culture. Rows of Shops, accomodation and a number of tourist attractions have not been

\footnotetext{
${ }^{3}$ Interview with Cultural staff from Cultural service Bantul Regency, 2018
} 
able to represent the potential in Parangtritis tourist area.

The results of the study are (1) the local community has contributed to the development of the Parangtritis tourist area through local cultural activities, tourist attractions, providing visitors' needs. (2) the local government of Bantul Regency has programs related to empowerment in each of the Government Servives Office through small medium enterprises, tourism conscious groups and the construction of facilities and infrastructure. Because empowerment programs from local governments have not been specific to training related to services and business activities that are in accordance with tourist destinations.

Community participation in developing tourist attractions is still not attract to increase the tourist visits in Parangtritis tourist area. Synergy between the community, tourism service industry and the local government of Bantul Regency is needed to develop tourist areas without pressure on the environment, but development that can strengthen existing potential.

\section{SUGGESTION}

The program created by the local government of Bantul Regency is adjusted to the needs of the local community as a tourism service industry. The development of the Parangtritis tourist area is directed at strengthening local potential, namely a combination of natural tourist attraction, cultural and artificial tourism.

\section{REFERENCES}

Baiquni, M. And Susilawardani. 2002." Pembangunan Yang Tidak Berkelanjutan: Refleksi Kritis Pembangunan Indonesia. Yogyakarta: Transmedia Global Wacana.

Center for Planning and Tourism development UGM, 2000

Cohen, E. 1978. The Impact Of Tourism On The Physical Environment. Annals Of Tourism Research, 5, 215-237.

Davenport, J. \& Davenport, J. L. 2006. The Impact Of Tourism And Personal Leisure Transport On Coastal Environments: A Review. Estuarine, Coastal And Shelf Science, 67, 280-292.

Elliott, J. 1997. Tourism: Politics And Public Sector Management, Psychology Press.

Hall, C. M. 2001. Trends In Ocean And Coastal Tourism: The End Of The Last Frontier? Ocean \& Coastal Management, 44, 601-618.

Hulu, M., Baiquni, M., Fandeli, C. \& Wirasanti, N. 2018. Tourism Development Towards Economic Sustainability Of Local Communities In Parangtritis Tourism Area. Kne Social Sciences, 3, 359-366. 
Mihalič, T. 2000. Environmental Management Of A Tourist Destination: A Factor Of Tourism Competitiveness. Tourism Management, 21, 65-78.

Miller, M. L. \& Auyong, J. 1991. Coastal Zone Tourism: A Potent Force Affecting Environment And Society. Marine Policy, 15, 75-99.

Murray, G. 2007. Constructing Paradise: The Impacts Of Big Tourism In The Mexican Coastal Zone. Coastal Management, 35, 339-355.

Neto, F. A New Approach To Sustainable Tourism Development: Moving Beyond Environmental Protection. Natural Resources Forum, 2003. Wiley Online Library, 212-222.

Center for Planning and Tourism development UGM, 2000: Parangtritis Tourism Object Development Master Plan.

Pigram, J. J. \& Wahab, S. 2005. Tourism, Development And Growth: The Challenge of Sustainability, Routledge.

Regional Regulation No. 10/2015 About Tourism Master Plan Development Bantul Regency.

Regional Regulation No.4/2015 About Spatial Planning Bantul Regency.

Sano, M., Gonzalez-Riancho, P., Areizaga, J. \& Medina, R. 2010. The Strategy For Coastal Sustainability: A Spanish Initiative For Iczm. Coastal Management, 38, 76-96.

Singh, S., Timothy, D. J. \& Dowling, R. K. 2003. Tourism In Destination Communities, Cabi.

Siry, H. Y. 2011. In Search Of Appropriate Approaches To Coastal Zone Management In Indonesia. Ocean \& Coastal Management, 54, 469-477.
Woosnam, K. M., Norman, W. C. \& Ying, T. 2009. Exploring The Theoretical Framework Of Emotional Solidarity Between Residents And Tourists. Journal Of Travel Research, 48, 245-258.

Yang, J., Ge, Y., Ge, Q., Xi, J. \& Li, X. 2016. Determinants Of Island Tourism Development: The Example Of Dachangshan Island. Tourism Management, 55, 261271.

Zahedi, S. 2008. Tourism Impact On Coastal Environment. Wit Transactions On The Built Environment, 99, 45-57. 